\title{
Discourse in Indonesian Newspaper Reports: A Case Study of Indonesian President Election Campaign from 2014 to 2019
}

\section{Dudi Iskandar}

Lecturer at Communication Science Faculty of Budi Luhur University, South Jakarta,dudi.iskandar@budiluhur.ac.id

\begin{abstract}
Today's political realities of media are alignments. There is no political contestation that does not involve the media. There was a radical change in media institutions from watchdog to involved in power struggles. This is where the media becomes political actors. Media involvement in political contestation is realized by constructing news that benefits certain political parties or candidates. Then the news presented to the public will build discourse that benefits certain parties and candidates. Media alignments with certain candidates can be seen in the 2014 and 2019 presidential election campaigns. Amid in the political interests of the contestants, journalism as the main product of the media is challenged to remain in principle and the journalistic code of ethics. The focus of this research is the headlines news, including photographs in Kompas newspaper, Koran Sindo newspaper, and Media Indonesia newspaper, the 8th and 14th editions of April 2019. With a qualitative approach and using critical language analysis research methods of Roger Fowler et al, this study found. First, the news in Kompas newspaper, Koran Sindo newspaper, and Media Indonesia newspaper in the 2014 and 2019 presidential election campaigns took sides politically, either openly or secretly. Second, the reader must change the perspective of media reality today. The alignment of media politics with certain candidates is a necessity. The two findings have implications for the third finding, there must be a change in the journalistic code of ethics which now seems out of date.
\end{abstract}

Keywords :

discourse, news, politics, newspaper, presidential election campaign

Article Received: 18 October 2020, Revised: 3 November 2020, Accepted: 24 December 2020

\section{INTRODUCTION}

News in a newspaper is not just a series of facts arranged into a sentence. It is also a representation of the thoughts and attitudes of journalists. All cultural backgrounds, relationships, and journalist education influence how facts are constructed. The style of presentation, searching, finding, and constructing facts, journalists have been constructed with a variety of things that are not neutral and independent (Brooersma, 2010). Journalists are not robots who are not affected by the environment. In the personal sphere, he builds on the basis of education, experience, knowledge, and values. Therefore, every news is contained bias. This condition is very difficult to avoid. The news is not in a vacuum. He is always in a social context and in certain struggles. It is normal if the news is always in a situation and partisanship. (Iskandar, 2015).

Many considerations of an event become news in the media, among others, politics, economy, culture, ideology, business, and so on. Ideological considerations occur because of the owner's factors or the values they live. Political considerations depart from the fact that the press is inseparable from political life (Ologunju and Ajadi, 2014). Moreover, the press is referred to as the fourth estate of democracy. While business interests are related to income from advertising. These three considerations also affect the news perspective. This is where the editorial policy determines the direction of the news. There is no completely objective news. He always interfered with the thoughts and attitudes of journalists and editorial staff. Today's media owners are large conglomerates, political rulers and vested interests.

When newspaper news is presented to the public sphere, it will become a discourse. Discourse is a unified whole between text, context, and social practice (Routsalainen and Villi, 2018). Discourse is a way of producing social knowledge and practices, forms of 
subjectivity that are formed from it, the power relations behind such social knowledge and practices and the interrelations between them (Piliang, 2011).

Discourse according to Hamad (2010) has two meanings. First, a discourse (with a small d) that looks at how language is used in its place to act out the linguistic aspect. Second, Discourse (with large D) which arranges elements of discourse (with small d) together with nonlinguistic elements to act out activities, views, and identities. Some forms of non-language include ideology, economics, politics, culture, and so on. In politics, discourse analysis is the practice of using language, especially political language (Baider, 2014). There are two forms of discourse. Namely, as a series of interrelated sentences. He connects propositions so that they form a unified structure so that there is harmony between the sentences. Second, discourse as the highest and most comprehensive language unit.

Historically Foucault (1979) became the initial drafter of the term discourse. The term discourse does not stand alone. He is related to Foucault's other distinctive terms such as episteme, archeology, and genealogy. From this came the theory of the relation of knowledge and power or power and knowledge. Power works through language.

Discourse is the entire conceptual area in which knowledge is constructed and produced. Discourse in this context is the whole field or domain in which language is used in certain ways. Broadly speaking, the Foucault version of discourse can be understood as everything that is written, everything that is communicated using certain rules and signs, especially signs of language. Because language is the only tool to understand the reality of the world. (Lubis, 2014). In Foucault's understanding, language is a system of thought; system of ideas that are interconnected with one another that gives us knowledge (Lubis, 2014).

The role of the media in politics today has changed greatly. Media is not only a social and economic/business institution. Now, the media as an institution has become a political actor. This means that political actors are not only politicians, activists and professionals. So the media is not a neutral domain where various interests and meanings of various groups will receive equal treatment. Media is a subject that constructs reality based on its interpretation and definition to be distributed to the public, including in political affairs.

Journalism is closely related to all fields of life, including politics, as appointed by Brian McNair (2000), Gans (2003), McQuail (2013). In every political contestation, journalism must be involved in it. All aspects of politics are the subject of the news. Here comes the terminology of political journalism (Nete Norgaard Kristensen, 2015).

Especially on the presidential election campaign in the media using critical discourse analysis, several studies that have been conducted such as Mohammed Ademilokun in Nigeria (2011), Habib Gowhary et al inIran (2013), James Nyachae Michira in Kenya (2014), and Lucía María Ramos Palacios in United States of America (2016).

This research was conducted on the Indonesian presidential election campaign in 2014 and 2019. With various perspectives, interests, and missions, the media reported the political event in Indonesia. Initial findings show that all media are actively involved in supporting a particular presidential candidate.

In the 2014 presidential election, Media Indonesia newspaper was on the side of Joko Widodo-Jusuf Kalla's pair. Media Indonesia defended Joko Widodo-Jusuf Kalla because the Nasdem Party which in fact belonged to Surya Paloh, the big boss of Media Group, was a supporting political party besides the Indonesian Democratic Party of Struggle (PDIP) and the National Awakening Party (PKB), and the People's Conscience Party (Hanura).

On the other hand, Koran Sindo newspaper is owned by Hary Tanoesoedibja. Therefore 
Koran Sindo newspaper defended Prabowo-Hatta Rajasa. After failing to advance as a vicepresidential candidate from Hanura in partnership with Wiranto, Hanura General Chairperson Hary Tanoesoedibja crossed into Prabowo-Hatta Rajasa's stronghold supported by the Great Indonesia Movement Party (Gerindra), Golkar Party, the National Mandate Party (PAN), and the National Mandate Party (PAN), and Prosperous Justice Party (PKS) as well as the Democratic Party which also shyly supported.

In the 2019 Presidential Election, there was a slight map change. Hary Tanoesoedibja's Koran Sindo newspaper with Perindo wagon crossing into the stronghold of Joko WidodoMa'ruf Amin. And, the Democratic Party firmly formed a coalition with the Prabowo-Sandiaga Uno camp. Meanwhile, the People's Conscience Party (Hanura) who did not qualify for the Parliamentary Threshold could not provide support to the 2019 presidential-vice presidential candidates.

Whereas Kompas newspaper alignments with Joko Widodo-Jusuf Kalla (2014) and Joko Widodo-Maruf Amin (2019) are due to ideological similarities with the bearers, especially with PDIP - rooted in the PDI - which was a fusion of political parties from national and Christian circles in 1972. Historically Kompas newspaper was founded by people from the Indonesian Catholic Party background (Frans Seda, PK Ojong, and Jacob Oetama). (Iskandar at al, 2017)

\section{RESEARCH METHOD}

The research approach used is qualitative. The qualitative approach departs from the basic assumption that humans as free, independent, and creative beings can create their reality. Yin (2011) states that one of the unique characteristics of qualitative research is the focus on the meaning of life that is under the surface or not visible, as a representation of people's views or perspectives. Qualitative research is to gain an understanding of reality through inductive thinking processes.
In addition to the constructivist paradigm, a qualitative paradigm develops critically. This model is a criticism of the constructivist paradigm which views reality as made by humans "innocently." Hence the basic assumption of the mythical paradigm is "suspicion" of all reality; there is pseudo-reality. The critical paradigm views all reality as being formed by humans who have certain interests, especially power. Therefore all reality has a certain ideology (Burak, 2018). Ideology, said Fairclough (1995) is the meaning that serves power.

Thus, the paradigm in this study is suspicion of the text. The suspicion is that the media texts studied contain a certain ideology; interests. In practice, media texts according to the critical paradigm must be dismantled to find the original meaning by one of them, interrogating text (Ramanathan and Hoon, 2015). The critical paradigm for media texts aims to dismantle the hidden intentions in one story. The critical paradigm does not merely see the text as an object of language study. $\mathrm{He}$ is seen as a tool and practice of power.

One of the research methods in the critical paradigm is the critical language analysis method of Fowler et al (1979). This method divides discourse into four categories. First, classification is related to the analysis of words, sentences, and terms used by Kompas newspaper, Koran Sindo newspaper, and Media Indonesia newspaper in shaping the construction of the 2019 presidential election campaign discourse. Second, perspective. This category is used to see Kompas newspaper, Koran Sindo newspaper, and Media Indonesia newspaper perspective in shaping the discourse of the 2019 presidential election campaign. Third, the discourse battle. The third category wants to see the discourse battle in the news that is published in the Kompas newspaper, Koran Sindo newspaper, and Media Indonesia newspaper. Fourth, domination or marginalization. This section aims to look at those who dominate and those who are marginalized in the news text 
produced by the Kompas newspaper, Koran Sindo

newspaper, and Media Indonesia newspaper

Table I

Critical Language Analysis Method of Fowler et al (1979)

\begin{tabular}{|l|l|}
\hline \multicolumn{1}{|c|}{ Catagories } & \multicolumn{1}{c|}{ Explain } \\
\hline Classification & $\begin{array}{l}\text { This item relates to the analysis of words, sentences, and } \\
\text { terms used }\end{array}$ \\
\hline Perspective & $\begin{array}{l}\text { This category is used newspapers perspective in shaping } \\
\text { the discourse }\end{array}$ \\
\hline Discourse Battle & $\begin{array}{l}\text { This category wants to see the discourse battle in the } \\
\text { news that is published }\end{array}$ \\
\hline Domination/Marginalization. & $\begin{array}{l}\text { This section aims to look at those who dominate and } \\
\text { those who are marginalized in the news text produced }\end{array}$ \\
\hline
\end{tabular}

Table II

Headlines news of Kompas newspaper, Koran Sindo newspaper, and Media Indonesia newspaper about Presidential Election Campaign, $8^{\text {th }}$ dan $14^{\text {th }} 2019$ editions

\begin{tabular}{|l|l|l|l|}
\hline No & \multicolumn{1}{|c|}{ Edition } & \multicolumn{1}{|c|}{ Tittle } & \multicolumn{1}{|c|}{ Photographs } \\
\hline 1 & $\begin{array}{l}\text { Kompas newspaper, } 8^{\text {th }} \text { April } \\
2019\end{array}$ & $\begin{array}{l}\text { Pekan Terakhir Makin Dinamis } \\
\text { (The Last Week is More } \\
\text { Dynamic) }\end{array}$ & $\begin{array}{l}\text { Joko Widodo and } \\
\text { Prabowo Subianto }\end{array}$ \\
\hline 2 & $\begin{array}{l}\text { Kompas newspaper, 14 } \\
\text { th }\end{array}$ & $\begin{array}{l}\text { Spril } \\
\text { (It's Time to Make Your } \\
\text { Choice) }\end{array}$ & $\begin{array}{l}\text { Joko Widodo and } \\
\text { Sandiaga Uno }\end{array}$ \\
\hline 3 & $\begin{array}{l}\text { Koran Sindo newspaper, 14 } \\
\text { th } \\
\text { (Time to Make a Choice) }\end{array}$ & $\begin{array}{l}\text { Four photographs } \\
\text { consisting of Joko } \\
\text { Widodo, Ma'ruf } \\
\text { Amin, Hary } \\
\text { Tanoesoedibjo, and } \\
\text { his supporters. }\end{array}$ \\
\hline 4 & $\begin{array}{l}\text { Media Indonesia newspaper, } 8^{\text {th }} \\
\text { April 2019 }\end{array}$ & $\begin{array}{l}\text { SBY Kritisi Kampanye } \\
\text { Prabowo } \\
\text { (SBY Criticizes Prabowo's } \\
\text { Campaign) }\end{array}$ & Nothing \\
\hline 5 & $\begin{array}{l}\text { Media Indonesia newspaper, 14 } \\
\text { April 2019 }\end{array}$ & $\begin{array}{l}\text { Jokowi Mantabkan Ekonomi, } \\
\text { Prabowo Salahkan Masa Lalu } \\
\text { (Jokowi Strengthens the } \\
\text { Economy, Prabowo Blames the } \\
\text { Past) }\end{array}$ & $\begin{array}{l}\text { Joko Widodo in the } \\
\text { middle of his } \\
\text { supporters }\end{array}$ \\
\hline
\end{tabular}

The results of the research by Roger Fowler et al connected to the reality of contemporary media and journalism. As is the case with qualitative research, the results are discussed through library research and analysis of library data (documents) and critically analyze the phenomena and realities of contemporary media and journalism. Literature research (document analysis) is one way to extract data from books, 
journals, or sites by the themes discussed in this study.

The table below presents the results of an analysis of the Critical Language Analysis Method of Fowler et al (1979) to Kompas newspaper, 8th and 14th April 2019. As is usual the Kompas newspaper news is all flat and only informative.

\section{RESULTS}

\section{a. Kompas Newspaper}

Data and facts are presented as-is. Kompas tries to be neutral and balanced with two partners. No discourse that is highlighted by the two candidates for president-vice president. No pressures and controversial or prominent information.

Table III

Critical Language Analysis Method of Fowler et al (1979) to Kompas newspaper, $8^{\text {th }}$ April 2019

\begin{tabular}{|l|l|}
\hline \multicolumn{1}{|c|}{ Catagories } & \multicolumn{1}{c|}{ Explain } \\
\hline Classification & $\begin{array}{l}\text { Prabowo Subianto-Sandiaga Uno (6 times) } \\
\text { vs } \\
\text { Joko Widodo-Ma'ruf Amin (6 times) }\end{array}$ \\
\hline Perspective & $\begin{array}{l}\text { Prabowo Subianto-Sandiaga Uno : Islam } \\
\text { vs } \\
\text { Joko Widodo-Ma'ruf Amin : Culture }\end{array}$ \\
\hline Discourse Battle & $\begin{array}{l}\text { Prabowo Subianto-Sandiaga Uno : Baldatun thoyyibatun } \\
\text { wa Robbun Ghofur } \\
\text { vs } \\
\text { Joko Widodo-Ma'ruf Amin : Unite and harmony }\end{array}$ \\
\hline Domination/Marginalization. & $\begin{array}{l}\text { Prabowo Subianto-Sandiaga Uno : Not inclusive } \\
\text { vs } \\
\text { Joko Widodo-Ma'ruf Amin : Cultural Parade }\end{array}$ \\
\hline Photographs & $\begin{array}{l}\text { Kompas newspaper tries to display Joko Widodo and } \\
\text { Prabowo Subianto in a balancing. But, if examined } \\
\text { closely Joko Widodo more eye-catching. }\end{array}$ \\
\hline
\end{tabular}

Table IV

Critical Language Analysis Method of Fowler et al (1979) to Kompas newspaper, $14^{\text {th }}$ April 2019

\begin{tabular}{|l|l|}
\hline \multicolumn{1}{|c|}{ Catagories } & \multicolumn{1}{c|}{ Explain } \\
\hline Classification & $\begin{array}{l}\text { Prabowo Subianto-Sandiaga Uno (9 times) } \\
\text { vs } \\
\text { Joko Widodo-Ma'ruf Amin (9 times) }\end{array}$ \\
\hline Perspective & $\begin{array}{l}\text { Prabowo Subianto-Sandiaga Uno : Indonesia Wrong } \\
\text { Direction } \\
\text { vs } \\
\text { Joko Widodo-Ma'ruf Amin : Economic Growth and } \\
\text { Equality }\end{array}$ \\
\hline Discourse Battle & $\begin{array}{l}\text { Prabowo Subianto-Sandiaga Uno : Development of } \\
\text { Technology-Based }\end{array}$ \\
& $\begin{array}{l}\text { vs } \\
\text { Joko Widodo-Ma'ruf Amin : Development of } \\
\text { Indonesian Character }\end{array}$ \\
\hline Domination/Marginalization. & Prabowo Subianto-Sandiaga Uno : Micro economy \\
\hline
\end{tabular}




\begin{tabular}{|l|l|}
\hline & $\begin{array}{l}\text { vs } \\
\text { Joko Widodo-Ma'ruf Amin : Safe and peaceful general } \\
\text { elections }\end{array}$ \\
\hline Photographs & $\begin{array}{l}\text { Kompas newspaper tries to display Joko Widodo and } \\
\text { Sandiaga Uno in a balancing. But, if examined closely } \\
\text { Joko Widodo, more eye-catching. }\end{array}$ \\
\hline
\end{tabular}

According to Hamad (2004), there are three strategies and styles of Kompas newspaper in peeling something sensitive. First, the middle road model; suing indirectly; criticize but delivered politely, impressed in circles and obscuring the message to be conveyed. Second, the heaven wind model; in peeling Kompas newspaper not suing or questioning certain things; but more than an appeal and hope. Third, the guard dog model, which is open and uses a bolder one. In political news, according to Ibn Hamad, Kompas newspaper writes more safely.

In the context of reporting, Kompas newspaper prioritizes the company's sustainability rather than overseeing power. In other languages, the economic factor of business is number two, whereas overseeing power is the umpteenth number and can be done in various ways. Naturally, if Kompas newspaper did not want to be confrontational, blindly, and firm in attitude.
The attitude of Kompas newspaper in the current news is a manifestation of the attitude and will of Jakob Oetama (along with six other editors) to sign an apology letter to President Soeharto when he was banned in 1978. This apology is a guarantee for Kompas newspaper to be published again,

\section{b. Koran Sindo newspaper dan Media Indonesia newspaper}

Unlike Kompas newspaper, which did not show its political alignments, Koran Sindo newspaper and Media Indonesia newspaper were so open to supporting the pair Joko Widodo-Ma'ruf Amin. Both expressly stated their political support through the news presented as listed in the table below. The support of Koran Sindo newspaper and Media Indonesia newspaper is realized through news texts and photo displays of Joko Widodo-Ma'ruf Amin.

Table V

Critical Language Analysis Method of Fowler et al (1979) to Koran Sindo newspaper, $14^{\text {th }}$ April 2019

\begin{tabular}{|l|l|}
\hline \multicolumn{1}{|c|}{ Catagories } & \multicolumn{1}{c|}{ Explain } \\
\hline Classification & $\begin{array}{l}\text { Prabowo Subianto-Sandiaga Uno : (8 times) } \\
\text { vs } \\
\text { Joko Widodo-Ma'ruf Amin : (17 times) }\end{array}$ \\
\hline Perspective & $\begin{array}{l}\text { Prabowo Subianto-Sandiaga Uno : Indonesia Wrong } \\
\text { Direction } \\
\text { vs } \\
\text { Joko Widodo-Ma'ruf Amin : Economic Growth and } \\
\text { Equality }\end{array}$ \\
\hline Discourse Battle & $\begin{array}{l}\text { Prabowo Subianto-Sandiaga Uno : Economy Crisis } \\
\text { vs }\end{array}$ \\
\hline Domination/Marginalization. & $\begin{array}{l}\text { Prabowo Subianto-Sandiaga Uno : Promise } \\
\text { vs } \\
\text { Joko Widodo-Ma'ruf Amin : Success }\end{array}$ \\
\hline
\end{tabular}




\begin{tabular}{|l|l|}
\hline Photographs & $\begin{array}{l}\text { Almost one page is full of news and photos of Joko } \\
\text { Widodo-Ma'ruf Amin. Four photos consisting of Joko } \\
\text { Widodo, Ma'ruf Amin, Hary Tanoesoedibjo, and his } \\
\text { supporters. }\end{array}$ \\
\hline
\end{tabular}

Table VI

Critical Language Analysis Method of Roger Fowler et al (1979) to Media Indonesia newspaper, $8^{\text {th }}$ April 2019

\begin{tabular}{|l|l|}
\hline \multicolumn{1}{|c|}{ Catagories } & \multicolumn{1}{c|}{ Explain } \\
\hline Classification & $\begin{array}{l}\text { Criticism towards Prabowo Subianto-Sandiaga Uno from } \\
\text { Coalition Members }\end{array}$ \\
\hline Perspective & $\begin{array}{l}\text { Dropping fellow coalition members. Appoints Prabowo- } \\
\text { Sandiaga Uno unsolid coalition }\end{array}$ \\
\hline Discourse Battle & Intolerant \\
\hline Domination/Marginalization. & Politics of Identity (212 movement) \\
\hline Photographs & None \\
\hline
\end{tabular}

Table VII

Critical Language Analysis Method of Fowler et al (1979) to Media Indonesia newspaper, $14^{\text {th }}$ April 2019

\begin{tabular}{|l|l|}
\hline \multicolumn{1}{|c|}{ Catagories } & \multicolumn{1}{|c|}{ Explain } \\
\hline Classification & $\begin{array}{l}\text { Prabowo Subianto-Sandiaga Uno (8 times) } \\
\text { vs } \\
\text { Joko Widodo-Ma'ruf Amin (8 times ) }\end{array}$ \\
\hline Perspective & $\begin{array}{l}\text { Prabowo Subianto-Sandiaga Uno : Indonesia Wrong } \\
\text { Direction } \\
\text { vs } \\
\text { Joko Widodo-Ma'ruf Amin : Economic Growth and } \\
\text { Equality }\end{array}$ \\
\hline Discourse Battle & $\begin{array}{l}\text { Prabowo Subianto-Sandiaga Uno : Integrity Pact } \\
\text { vs } \\
\text { Joko Widodo-Ma'ruf Amin : Equity Development }\end{array}$ \\
\hline Domination/Marginalization. & $\begin{array}{l}\text { Attack to Prabowo Subianto-Sandiaga Uno } \\
\text { vs } \\
\text { Praise to Joko Widodo-Ma'ruf Amin }\end{array}$ \\
\hline Photographs & $\begin{array}{l}\text { Just like Koran Sindo newspaper, Media Indonesia } \\
\text { newspaper displays half a page for Joko Widodo's photo } \\
\text { in the middle of his supporters }\end{array}$ \\
\hline
\end{tabular}

\section{Discussions}

If it is portrayed, the language style of Kompas newspaper and Media Indonesia newspaper follows the character and character of its owner. Kompas newspaper in the style of Jakob Oetama who is calm, seductive, and calculating but has extraordinary influence. In contrast, Surya Paloh's style as the owner of Media Indonesia newspaper tends to be straightforward, assertive, and explosive. The personalities of the owners of the two media 
greatly affect their respective journalistic styles (Saddhono, 2015; 2020). Meanwhile, Koran Sindo newspaper followed Kompas newspaper's flowing style while still paying attention to readers as their market. Media construction is a reflection of the dominant culture, therefore the media defines and offers a reality that suits their interests in various versions and arguments. (Curran, 2002)

News in Koran Sindo newspaper and Media Indonesia newspaper shows that the media is an extension of individual interests and personifications. Surya Paloh and Hary Tanoesoedibjo as the owners of Media Indonesia newspaper and Koran Sindo newspaper used their media to vent their political desires by ignoring journalistic principles, elements, and ethics. Through their media, both of them campaigned vulgarly for Jokowi-Ma'ruf Amin. Political interest or political alignments has proven to be a separate social problem. The public interest was ignored by Surya Paloh and Hary Tanoesoedibjo because it was occupied by the interests of both political parties. (Nasdem party and Perindo party).

In this context, Media Indonesia newspaper and Koran Sindo newspaper have violated the independent principles stated in the Journalistic Code of Ethics. The principle of independence in the work of Indonesian journalists is contained in Article 1 of the Journalistic Code of Ethics. Indonesian journalists are independent, produce news that is accurate, balanced, and have no bad intentions.

This article is then explained in its interpretation. Independent means reporting events or facts following the voice of conscience without interference, coercion, intervention from other parties including the owner of the press company. Independent media are detached from political power and economic interests and represent public interests. (Bennet and Strange (ed). 2015), (Beers, 2006)

Table IX

Comparison of Newspapers Discourse in the 2019 Presidential Election Campaign

\begin{tabular}{|c|c|c|c|c|}
\hline Media/Catagories & Classification & Perspective & $\begin{array}{l}\text { Discourse } \\
\text { Battle }\end{array}$ & $\begin{array}{l}\text { Domination/Mar } \\
\text { ginalization }\end{array}$ \\
\hline $\begin{array}{l}\text { Kompas } \\
\text { newspaper, } \\
8^{\text {th }} \text { April } 2019\end{array}$ & $\begin{array}{l}\text { Prabowo } \\
\text { Subianto- } \\
\text { Sandiaga Uno } \\
\text { (6 times) } \\
\text { vs } \\
\text { Joko Widodo- } \\
\text { Ma'ruf Amin } \\
\text { (6 times) }\end{array}$ & $\begin{array}{l}\text { Prabowo } \\
\text { Subianto- } \\
\text { Sandiaga Uno : } \\
\text { Islam } \\
\text { vs } \\
\text { Joko Widodo- } \\
\text { Ma'ruf Amin : } \\
\text { Culture }\end{array}$ & $\begin{array}{l}\text { Prabowo } \\
\text { Subianto- } \\
\text { Sandiaga Uno : } \\
\text { Baldatun } \\
\text { thoyyibatun wa } \\
\text { Robbun Ghofur } \\
\text { vs } \\
\text { Joko Widodo- } \\
\text { Ma'ruf Amin : } \\
\text { Unite and } \\
\text { harmony }\end{array}$ & $\begin{array}{l}\text { Prabowo } \\
\text { Subianto- } \\
\text { Sandiaga Uno: } \\
\text { Not inclusive } \\
\text { vs } \\
\text { Joko Widodo- } \\
\text { Ma'ruf Amin : } \\
\text { Cultural Parade }\end{array}$ \\
\hline Photographs & \multicolumn{4}{|c|}{$\begin{array}{l}\text { Kompas tries to display Joko Widodo and Prabowo Subianto in a balanced } \\
\text { way even if examined closely by Joko Widodo, which is more eye- } \\
\text { catching. }\end{array}$} \\
\hline $\begin{array}{l}\text { Kompas } \\
\text { newspaper, } \\
14^{\text {th }} \text { April } 2019\end{array}$ & $\begin{array}{l}\text { Prabowo } \\
\text { Subianto- } \\
\text { Sandiaga Uno : } \\
\text { Islam } \\
\text { vs }\end{array}$ & $\begin{array}{l}\text { Prabowo } \\
\text { Subianto- } \\
\text { Sandiaga Uno : } \\
\text { Indonesia Wrong } \\
\text { Direction }\end{array}$ & $\begin{array}{l}\text { Prabowo } \\
\text { Subianto- } \\
\text { Sandiaga Uno : } \\
\text { Development of } \\
\text { Technology- }\end{array}$ & $\begin{array}{l}\text { Prabowo } \\
\text { Subianto- } \\
\text { Sandiaga Uno : } \\
\text { Micro economy } \\
\text { vs }\end{array}$ \\
\hline
\end{tabular}




\begin{tabular}{|c|c|c|c|c|}
\hline & $\begin{array}{l}\text { Joko Widodo- } \\
\text { Ma'ruf Amin : } \\
\text { Culture }\end{array}$ & $\begin{array}{l}\text { vs } \\
\text { Joko Widodo- } \\
\text { Ma'ruf Amin : } \\
\text { Economic Growth } \\
\text { and Equality }\end{array}$ & $\begin{array}{l}\text { Based } \\
\text { vs } \\
\text { Joko Widodo- } \\
\text { Ma'ruf Amin: } \\
\text { Development of } \\
\text { Indonesian } \\
\text { Character }\end{array}$ & $\begin{array}{l}\text { Joko Widodo- } \\
\text { Ma'ruf Amin : } \\
\text { Safe and peaceful } \\
\text { general elections }\end{array}$ \\
\hline Photographs & \multicolumn{4}{|c|}{$\begin{array}{l}\text { Kompas tries to display Joko Widodo and Sandiaga Uno in a balanced way } \\
\text { even if examined closely by Joko Widodo, which is more eye-catching. }\end{array}$} \\
\hline $\begin{array}{l}\text { Koran Sindo } \\
\text { newspaper, } \\
8^{\text {th }} \text { April } 2019\end{array}$ & $\begin{array}{l}\text { Prabowo } \\
\text { Subianto- } \\
\text { Sandiaga Uno : } \\
\text { (8 times) } \\
\text { vs } \\
\text { Joko Widodo- } \\
\text { Ma'ruf Amin : } \\
\text { (17 times) }\end{array}$ & $\begin{array}{l}\text { Prabowo } \\
\text { Subianto- } \\
\text { Sandiaga Uno : } \\
\text { Indonesia Wrong } \\
\text { Direction } \\
\text { vs } \\
\text { Joko Widodo- } \\
\text { Ma'ruf Amin : } \\
\text { Economic Growth } \\
\text { and Equality }\end{array}$ & $\begin{array}{l}\text { Prabowo } \\
\text { Subianto- } \\
\text { Sandiaga Uno : } \\
\text { Economy Crisis } \\
\text { vs } \\
\text { Joko Widodo- } \\
\text { Ma'ruf Amin : } \\
\text { Economic } \\
\text { Independence }\end{array}$ & $\begin{array}{l}\text { Prabowo } \\
\text { Subianto- } \\
\text { Sandiaga Uno : } \\
\text { Promise } \\
\text { vs } \\
\text { Joko Widodo- } \\
\text { Ma'ruf Amin : } \\
\text { Success }\end{array}$ \\
\hline Photographs & \multicolumn{4}{|c|}{$\begin{array}{l}\text { Almost one page is full of news and photos of Joko Widodo-Ma'ruf Amin. } \\
\text { Four photos consisting of Joko Widodo, Ma'ruf Amin, Hary } \\
\text { Tanoesoedibjo, and his supporters. }\end{array}$} \\
\hline $\begin{array}{l}\text { Media Indonesia } \\
\text { newspaper, } 8^{\text {th }} \\
\text { April } 2019\end{array}$ & $\begin{array}{l}\text { Criticism } \\
\text { towards } \\
\text { Prabowo } \\
\text { Subianto- } \\
\text { Sandiaga Uno } \\
\text { from Coalition } \\
\text { Members }\end{array}$ & $\begin{array}{l}\text { Dropping Fellow } \\
\text { Coalition } \\
\text { Members. } \\
\text { Appoints } \\
\text { Prabowo- } \\
\text { Sandiaga Uno } \\
\text { Uno Solid } \\
\text { Coalition }\end{array}$ & Intolerant & $\begin{array}{l}\text { Politics of } \\
\text { Identity }(212 \\
\text { movement })\end{array}$ \\
\hline $\begin{array}{l}\text { Media Indonesia } \\
\text { newspaper, } 14^{\text {th }} \\
\text { April } 2019\end{array}$ & $\begin{array}{l}\text { Prabowo } \\
\text { Subianto- } \\
\text { Sandiaga Uno } \\
\text { (8 times) } \\
\text { vs } \\
\text { Joko Widodo- } \\
\text { Ma'ruf Amin } \\
\text { (8 times) }\end{array}$ & $\begin{array}{l}\text { Prabowo } \\
\text { Subianto- } \\
\text { Sandiaga Uno : } \\
\text { Indonesia Wrong } \\
\text { Direction } \\
\text { vs } \\
\text { Joko Widodo- } \\
\text { Ma'ruf Amin : } \\
\text { Economic Growth } \\
\text { and Equality }\end{array}$ & $\begin{array}{l}\text { Prabowo } \\
\text { Subianto- } \\
\text { Sandiaga Uno : } \\
\text { Integrity Pact } \\
\text { vs } \\
\text { Joko Widodo- } \\
\text { Ma'ruf Amin : } \\
\text { Equity } \\
\text { Development }\end{array}$ & $\begin{array}{l}\text { Attack to } \\
\text { Prabowo } \\
\text { Subianto- } \\
\text { Sandiaga Uno } \\
\text { vs } \\
\text { Praise to Joko } \\
\text { Widodo-Ma'ruf } \\
\text { Amin }\end{array}$ \\
\hline Photographs & \multicolumn{4}{|c|}{$\begin{array}{l}\text { Just like Koran Sindo, Media Indonesia displays half a page for Joko } \\
\text { Widodo's photo in the middle of his supporters }\end{array}$} \\
\hline
\end{tabular}


If traced from the 2014 presidential election campaign (Iskandar et al. 2017), the comparison of discourse in Kompas newspaper,
Koran Sindo newspaper, and Media Indonesia newspaper reports on the two big campaigns can be described as the table below.

Table X

Newspaper Discourse Reports in Presidential Election Campaigns in 2014 and 2019

\begin{tabular}{|l|l|l|}
\hline \multicolumn{1}{|c|}{ Discourse/Year } & \multicolumn{1}{c|}{$\mathbf{2 0 1 4}$} & \multicolumn{1}{c|}{$\mathbf{2 0 1 9}$} \\
\hline Human Right Issue & To attack Prabowo Subianto & Nothing \\
\hline Election Fraud & $\begin{array}{l}\text { Attack Prabowo with the } \\
\text { involvement of Babinsa } \\
\text { Pebat }\end{array}$ & $\begin{array}{l}\text { Attacking Jokowi as } \\
\text { incumbent }\end{array}$ \\
\hline $\begin{array}{l}\text { Presiden Susilo Bambang } \\
\text { Yudhoyono alignments }\end{array}$ & $\begin{array}{l}\text { Support Prabowo-Hatta Rajasa } \\
\text { shyly }\end{array}$ & $\begin{array}{l}\text { Including the Prabowo- } \\
\text { Sandiaga Uno coalition }\end{array}$ \\
\hline Music consert & To support Jokowi-Jusuf Kalla & $\begin{array}{l}\text { To support both pairs } \\
\text { (Prabowo Subianto-Sandiaga } \\
\text { Uno and Joko Widodo-Ma'ruf } \\
\text { Amin) }\end{array}$ \\
\hline
\end{tabular}

Table XI

Comparison of Newspapers Political Alignments in the 2014 (Iskandar et al. 2017) and 2019 Presidential Election Campaign

\begin{tabular}{|l|l|l|}
\hline \multicolumn{1}{|c|}{ Media/Year } & \multicolumn{1}{c|}{$\mathbf{2 0 1 4}$} & \multicolumn{1}{c|}{$\mathbf{2 0 1 9}$} \\
\hline Kompas newspaper & Trying to be balanced & Trying to be balanced \\
\hline Koran Sindo newspaper & Prabowo-Hatta Rajasa & Joko Widodo-Ma'ruf Amin \\
\hline Media Indonesia newspaper & Joko Widodo-Jusuf Kalla & Joko Widodo-Ma'ruf Amin \\
\hline
\end{tabular}

Five levels affect media content. Individuals, media routines, stages of the organization, extra media, and ideology. (Shoemaker and Reese (2014). No exception to the news of the 2019 presidential-vice presidential election campaign in Kompas newspaper, Sindo Newspapers newspaper, and Media Indonesia newspaper editions of the 8th and 14th April 2019. The five elements influence the construction of news that presented to the reader To assess that the reader can judge from five aspects of the pillars of journalism, namely, accuracy, balance, making government accountable, separating facts from editorial and advertising (Jones, 2009), Andre Cordiero dos Santos and Siane Gois Cavalcanti Rodrigues, 2017.
Meanwhile, Denis Mcquail, (2013) argues, journalistic truth criteria can be viewed from two aspects, content quality, and author quality or behavior. First, quality includes accuracy, reliability, looking right, balanced, completeness, and relevance. While from the aspect of the quality of the writer, it can be seen from the perspective of integrity, authenticity, personal truth, courage, and transparency. Second, the issue of media neutrality and independence. Independent does not mean as you wish. The media should fulfill strict journalistic principles. The most important principle is to preach the right and balanced thing in providing space and time opportunities for each party that is considered interested in the news. 
The objectivity of much political news sued is not related to people, but the method of data collection. Humans can not be separated from bias. Therefore, he must be disciplined in the verification of data and facts. From here the news will approach the truth as the aim of journalism itself. (Kovach and Rosentiels (2007). Truth is the basic value of journalism. The most important thing about journalism is to be accurate and offer reliable data and have a sincere intention (Lazaroiu, 2012).

On the other hand, many journalism experts consider that there are three fundamental problems in journalism. Neutrality, independence, and balance. Another problem is independence and truth which are the main objectives of journalism itself (Shojaei et al, 2013). So the objectivity of data and facts in the field becomes the most crucial in presenting news. (Jauhari, ed,
2012). The problem becomes more complicated if the facts and data come into contact with the political world. Lots of interests, hidden agendas, and dirty hands playing. Naturally in the news, political journalism is often associated with advertising, campaigns, propaganda, or agitation. The biggest influences are political actors, advertisements, and media owners who are involved in political content. (Iskandar, 2020)

Independence is the most important pillar of journalism. When independence is lost, the report becomes biased. Media independence is lost when it becomes a subsidiary or in media conglomerate Iggers (1999). Ownership of media companies spreads and systematically biases the news. Hence independence is independent of political power, economic interests, and represents the interests of the public (Bennet and Strange (ed). 2015).

\section{Table XII}

Analysis of Journalism Pillars in Kompas newspaper, Koran Sindo newspaper, and Media Indonesia newspaper during the 2019 Presidential Election Campaign

\begin{tabular}{|l|l|}
\hline \multicolumn{2}{|c|}{ Fairness } \\
\hline Kompas newspaper & $50: 50 /$ Trying to be balanced \\
\hline $\begin{array}{l}\text { Koran Sindo } \\
\text { newspaper }\end{array}$ & Support to Joko Widodo-Ma'ruf Amin \\
\hline $\begin{array}{l}\text { Media Indonesia } \\
\text { newspaper }\end{array}$ & Support to Joko Widodo-Ma'ruf Amin \\
\hline \multicolumn{2}{|c|}{ Objektive } \\
\hline Kompas newspaper & Factual, tends to be business oriented \\
\hline $\begin{array}{l}\text { Koran Sindo } \\
\text { newspaper }\end{array}$ & Factual in choosing facts based on political references \\
\hline $\begin{array}{l}\text { Media Indonesia } \\
\text { newspaper }\end{array}$ & Factual in choosing facts based on political references \\
\hline \multicolumn{2}{|c|}{ Cover both Sides } \\
\hline Kompas newspaper & $50: 50$ Trying to be balanced \\
\hline $\begin{array}{l}\text { Koran Sindo } \\
\text { newspaper }\end{array}$ & There is confirmation, 70:30 based on political references \\
\hline $\begin{array}{l}\text { Media Indonesia } \\
\text { newspaper }\end{array}$ & There is confirmation, 70:30 based on political references \\
\hline \multicolumn{2}{|c|}{ Neutrality } \\
\hline Kompas newspaper & Neutral among political parties \\
\hline $\begin{array}{l}\text { Koran Sindo } \\
\text { newspaper }\end{array}$ & Not neutral \\
\hline
\end{tabular}




\begin{tabular}{|l|l|}
\hline $\begin{array}{l}\text { Media Indonesia } \\
\text { newspaper }\end{array}$ & Not neutral \\
\hline \multicolumn{2}{|c|}{ Independency } \\
\hline Kompas newspaper & Not in a particular political party \\
\hline $\begin{array}{l}\text { Koran Sindo } \\
\text { newspaper }\end{array}$ & $\begin{array}{l}\text { Not independent because it is bound by the voice of the owner of a } \\
\text { political party who is also the party supporting Joko Widodo-Ma'ruf Amin }\end{array}$ \\
\hline $\begin{array}{l}\text { Media Indonesia } \\
\text { newspaper }\end{array}$ & $\begin{array}{l}\text { Not independent because it is bound by the voice of the owner of a } \\
\text { political party who is also the party supporting Joko Widodo-Ma'ruf Amin }\end{array}$ \\
\hline
\end{tabular}

\section{CONCLUSIONS}

Based on data and analysis to Kompas newspaper, Koran Sindo newspaper, and Media Indonesia newspaper headlines news, the 8th and 14th edition of April 2019 about the headlines news campaigns of Prabowo Subianto-Sandiaga Uno and Joko Widodo-Ma'ruf Amin can be drawn. First, the news in Kompas newspaper, Koran Sindo newspapers, and Media Indonesia newspaper on the 2014 and 2019 presidential and vice-presidential election campaigns took sides politically, either openly or secretly. Second, the reader must change the perspective of the political realities of contemporary media. That the alignment of media politics with certain candidates is a necessity. Third, there must be changes to the journalistic code of ethics which now look out of date due to the eroded development of communication and information technology. This is where the presence of the Press Council is awaited.

\section{Acknowledgment}

I would like to thank Budi Luhur University for fully funding this research. Also, I express thanks to all those who have helped with research and assisted in writing and publishing to international journals.

\section{REFERENCES}

[1] Abdullah, Faiz Sathi. (2014) Mass Media Discourse: A Critical Analysis Research Agenda. Social Sciences \& Humanities Journal homepage: http://www.pertanika.upm.edu.my/ Pertanika J. Soc. Sci. \& Hum. 22 (S): 1 - 16 (2014)
ISSN: 0128-7702 C) Universiti Putra Malaysia Press

[2] Ademilokun, Mohammed (2011). Discursive strategies in newspaper campaign advertisements for Nigeria's 2011 elections. Article in Discourse \& Communication . October 2013.2 DOI: $10.1177 / 1750481313494501$

[3] Baider, Fabienne (2014). Analysing Journalistic Discourse And Finding Opinions Semiautomatically?:A Case Study Of The 2007 And 2012 Presidential French Campaigns. Journal of Data Mining and Digital Humanities, Episciences.org.

[4] Beers, David. (2016) The Public Sphere and Online, Independent Journalism, https://www.researchgate.net/publication/242 518478_The_Public_Sphere and_Online_Ind ependent_Journalism

[5] Bennet, James and Niki Strange (ed) (2015). Media Independen : Working with Freedom or Working for Free? London. Routledge.

[6] Brooersma, Marcel. (2010). Journalism as performative discourse The importance of_form and style in journalism (In book Journalism and Meaning-Making: Reading the Newspaper (pp.15-35) Publisher: Hampton Press Editors: Verica Rupar.) Akses di $312328431 \quad$ (Accesed from https://www.researchgate.net/publication/312 328431_Journalism_as_performative_discour se_The_importance_of_form_and_style_in_j ournalism

[7] Burak, Begüm. (2018). Media Discourse, Ideology And Print Media In Turkey. e- 
Journal of New Media/Yeni Medya Elektronik Dergi - Ejnm ISSN: 2548-0200, April 2018 Volume 2 Issue 2, p.53-62 Doi No:

10.17932/Iau.Ejnm.25480200.2018.2/2.53-62

[8] Curran, James (2002). Media and Power.London. Routledge.

[9] Fairclough, Norman (1995). Critical Discourse Analysis. London and New York. Longman.

[10] Foucault, Michel (1979). Dicipline and Punish : The Birth of the Prison. Harmonswort. Penguin Books.

[11] Fowler, Roger. et. al. (1979). Language and Control. London. Routledge.

[12] Gans. Herbert J. (2003) Democracy and The News. Oxford University Press.

[13] Gowhary, Habib et.al. (2013). A Critical Discourse Analysis of the Electoral Talks of Iranian Presidential Candidates in 2013. 2nd Global Conference on Linguistics and Foreign Language Teaching, Linelt-2014, Dubai - United Arab Emirates, December 11 $-13,2014$

[14]Hamad, Ibnu. (2004) Konstruksi Realitas Politik di Media Massa; Sebuah Study Critical

Analysis Discourse (Construction of Political Reality in Mass Media; A Critical Analysis Discourse Study). Jakarta. Granit.

[15] Hamad. Ibnu Hamad. (2010). Komunikasi sebagai Wacana (Communication as Discourse). Jakarta. La Tofi Enterprise.

[16] Hole, Y., \& Snehal, P. \& Bhaskar, M. (2018). Service marketing and quality strategies. Periodicals of engineering and natural sciences, 6 (1), 182-196.

[17] Hole, Y., \& Snehal, P. \& Bhaskar, M. (2019). Porter's five forces model: gives you a competitive advantage. Journal of Advanced Research in Dynamical and Control System, 11 (4), 1436-1448.

[18] Iggers, Jeremy. (1999). Good News Bad News : Journalism Ethics and The Public Interest. Boulder. USA. Westview Press.
[19] Iskandar, Dudi Sabil. (2015). Keruntuhan Jurnalisme (The Fall of Journalism). Jakarta. Lentera Ilmu Cendikia.

[20] Iskandar, Dudi, (2017). Representasi Ideologi Kekuasaan dalam Konvergensi Media; Analisis Wacana Kritis Norman Fairclough Pemberitaan Kampanye Pemilihan Presiden 2014 di Kompas Grup, Media Grup, dan MNC Grup (Ideological Representation Of Power In Media Convergence ;Critical Discourse Analysis of Norman Fairclough in News Campaign 2014 Presidential Election in Kompas Group, Media Group, and MNC Group) Unpublished Dissertation. Padjadjaran University. Jatinangor. Sumedang. Jawa Barat, Indonesia.

[21] Iskandar, Dudi. et al. (2017) Political Journalism In Media Convergence Era Https://Www.Journalijdr.Com/PoliticalJournalism-Media-Convergence-Era

[22] Iskandar, Dudi at al. (2017). Ideological Representation Of PowerIn Media Convergence (Critical Discourse Analysis Of Norman Fairclough In News Campaign 2014 Presidential Election In Kompas Group, Media Group, And Mnc Group) Journal of Education and Social Sciences, Vol. 7, Issue 1, (June) ISSN 2289-1552.

https://www.jesoc.com/wpcontent/uploads/2017/08/JESOC7_69.pdf

[23] Iskandar, Dudi. (2019) Presidential Election Campaign in Islamic Newspaper https://www.atlantispress.com/proceedings/sores-19/125935310

[24] Jones, Alex S. (2009). Losing The News; The Future of The News That Feeds Democrarcy. Oxford University Press.

[25] Kovach, Bill and Tom Rosenstiel. (2007) The Elements of Journalism. New York,

a. Amerika Serikat: Three Rivers Press.

[26]Lazaroiu, George. (2012). Challangges to the Epistemology of Journalism; The Architecture of the Contemporary Mediascope. New York. Addleton Academic Publisher. 
[27]Lubis, Akhyar Yusuf. (2014). Teori dan Metodologi Ilmu Pengetahuan Sosial Budaya Kontemporer (Theory and Methodology of Contemporary Socio-Cultural Sciences). Jakarta. Rajagrafindo Persada.

[28] Lubis, Akhyar Yusuf. (2014). Postmodernisme; Teori dan Metode (Postmodernism; Theory and Method). Jakarta. Rajagrafindo Persada.

[29] McNair, Brian. (1995). An Introduction to Political Communication. Second Edition.

London. Routledge.

[30]McNair, Brian. (2000). Jurnalism and Demokracy; An Evaluation of the Political Public

[33] Nyachae Michira, James (2014). The Language of Politics: A CDA of the 2013 Kenyan Presidential Campaign Discourse. International Journal of Education and Research Vol. 2 No. 1 January 2014

[34] Olagunju, F. B. and Rasaq A. Ajadi (2014). The Media and the Ideology of Insecurity: A Critical Discourse Analysis of Two Editorials on Federal Government-Boko Haram Faceoff. Review of Journalism and Mass Communication June 2014, Vol. 2, No. 1, pp. 33-46ISSN: 2333-5742 (Print), 2333-5734 (Online)

[35] Piliang, Yasraf Amir. (2011). Dunia yang Dilipat (Folded World). Bandung. Matahari.

[36] Palacios, Lucía María Ramos (2018) The 2016 U.S. Presidential Debates: A Discourse Analysis Approach. Facultad de Filosofía y Letras.

https://rodin.uca.es/xmlui/bitstream/handle/1 0498/20674/Luc\%C3\%ADaRamos_TFG_EE II_FINAL.pdf?sequence $=1 \&$ isAllowed $=\mathrm{y}$

[37] Ramanathan, Renugah and Tan Bee Hoon. (2015) Application of Critical Discourse Analysis in Media Discourse Studies. The Southeast Asian Journal of English Language Studies - Vol 21(2): 57 - 68 . http://ejournals.ukm.my/31/article/view/9183

[38] Ruotsalainen, Juho and Mikko Villi. (2018). Hybrid Engagement: Discourses and
Sphare. London. Routlaedge.

[31] Mcquail, Denis. (2013). Journalism and Society. New Delhi, Sage Publications.

[32] Norgaard, Kristensen, Nete (2015). Cultural Journalism and Cultural Critique in a Changing Media Landscape. Journalism Practice Journal 9(6), 760-772. https://doi.org/10.1080/17512786.2015.1051 357. Acced from https://www.researchgate.net/publication/281 953611_Cultural_Journalism_and_Cultural_ Critique_in_a_changing_Media_Landscape

Scenarios of Entrepreneurial Journalism, Media and Communication (ISSN: 21832439) 2018, Volume 6, Issue 4, Pages 79-90 DOI: $10.17645 / \mathrm{mac} . v 6 i 4.1465$

[39] Saddhono, K., Wardani, N. E., \& Ulya, C. (2015). Sociopragmatic approach on discourse structure of friday prayer's sermon in java and madura island. J. of Lang and Lit, 6(1), 26-29.

[40] Saddhono, K. (2020). Indonesian Online Media's Construction of 'Maritime': A Critical Discourse Analysis. Pomorstvo, 34(1), 16-23.

[41] Schoemacher, Pamela J and Stephen D. Reese. (2014). Mediating the Message : Theories of Influences on Mass Media Content. Third Edition. New York. Routledge.

[42] Santos, André Cordeiro dos and Siane Gois Cavalcanti Rodrigues. (2017) The Presumed Impartiality of Journalistic Discourse: Ideological Positioning In Appropriating The Discourse Of Others. Alfa São Paulo Journal, v.61, n.3, p.609-628, 2017 http://doi.org/10.1590/1981-5794-1711-

[43] Shojaei, Amir et al, (2013). A CDA Approach to the Biased Interpretation and Representation of Ideologically Conflicting Ideas in Western Printed Media. Journal of Language Teaching and Research, Vol. 4, 
No. 4, pp. 858-868, July 2013 (C) 2013 Academy Publisher Manufactured in Finland. doi:10.4304/jltr.4.4.858-868

[44] Yin, Robert K. (2011). Qualitative Research from Star to Finish. New York, London Guilford Pres

[45] Yogesh Hole et al 2019 J. Phys.: Conf. Ser. 1362012121 